mothers not listed on the register. This should be remembered by doctors when they identify risk indicators and formulate action plans at case conferences.

Our study suggests that the children of women who have been assaulted are in need of increased protection. Staff in accident and emergency departments and general practitioners should be aware of the increased risk to children of victims of assault. When women seek medical treatment for injuries resulting from domestic violence the local child protection register should be checked, and if the victim or the assailant is listed the protection of the children in the family must be ensured.
We thank $\mathrm{Mr} \mathrm{R}$ Greenland, custodian of Avon child protection register, for his cooperation and support.

1 Browne K, Saqui F. Approaches to screening for child abuse and neglect. In: Browne K, Davies C, Stratton S, eds. Early prediction and prevention of child abuse. Chichester: John Wiley and Sons, 1988:57-85.

2 Borland M. Violence in the family. Manchester: Manchester University Press, 1976.

3 Hough M, Mayhew P. British crime survey. London: HMSO, 1985. (Home Office research study No 76.)

4 Shepherd JP, Shapland M, Scully C, Leslie IJ. Pattern, severity and aetiology of injury in assault. $7 R$ Soc Med 1990;28:75-8.

5 Department of Health. Working together: a guide to arrangements for interagency cooperation for the protection of children from abuse. London: HMSO, 1991.

(Accepted 9 February 1993)

\section{Should sewage workers and carers for people with learning disabilities be vaccinated for hepatitis $\mathbf{A}$ ?}

\section{J M Poole, A T Shakespeare}

Occupational Health Department, Central Clinic, Dudley DY2 7BX C J M Poole, consultant occupational physician A T Shakespeare, occupational health nurse

Correspondence to: Dr Poole.

BMF 1993;306:1 102
Immunisation against hepatitis $A$ with the newly developed vaccine of inactivated virus is recommended for people visiting parts of the world where the disease is endemic. It has been suggested that sewage workers and carers for people with learning disabilities may also benefit. ${ }^{12}$ There is little empirical evidence to support these recommendations apart from two reports of hepatitis in workers in contact with sewage sludge, the organic end product of sewage treatment. ${ }^{34} \mathrm{We}$ therefore undertook a cross sectional study to compare the prevalence of antibodies to hepatitis A virus in these two occupational groups with the prevalence in controls matched for age and social class.

\section{Subjects, methods, and results}

Forty sewage workers (gully cleaners, jetters, drain repairers, and cesspit emptiers) and 53 carers for children or adults with learning disabilities from two local authorities in the west midlands volunteered for the study after we had explained its purpose. The sewage workers' mean age was $42 \cdot 2$ (range $21-58$ ) years and the carers' $41 \cdot 3(19-63)$ years. We recruited 18 road workers (tarmac layers and pavers) aged $38 \cdot 7(20-62)$ years from one local authority as controls for the sewage workers and 20 office workers (in the personnel department) aged 41.0 (23-64) years as controls for the carers. We chose these controls to match the social class of the sewage workers and carers.

We took $10 \mathrm{ml}$ of blood from each subject. This was allowed to clot, and hepatitis A virus IgG was measured in the serum by enzyme linked immunosorbent assay (ELISA) (Syva MicroTrak total anti-HAV assay, Sorin Biomedica SpA, Italy). Cut off values were established according to the manufacturer's instructions by

Presence of antibodies to hepatitis $A$ virus (determined by ELISA) in sewage workers, carers for people with learning disabilities, and controls. Figures are numbers of subjects

\begin{tabular}{|c|c|c|}
\hline & \multicolumn{2}{|c|}{ Hepatitis A virus IgG } \\
\hline & Present & Absent \\
\hline Sewage workers for local authorities & 23 & 17 \\
\hline Dudley & 14 & 10 \\
\hline Wolverhampton & 9 & 7 \\
\hline Carers for people with learning disabilities & 19 & 34 \\
\hline Carers for adults & 13 & 20 \\
\hline Carers for children & 6 & 14 \\
\hline Controls & 13 & 25 \\
\hline Road workers & 6 & 12 \\
\hline Office workers & 7 & 13 \\
\hline
\end{tabular}

reference to control serum (Syva). Results for the groups were analysed by odds ratios.

The table shows the numbers of subjects who were seropositive for hepatitis A virus. Seropositivity was significantly more prevalent in the sewage workers than the controls (odds ratio 2.60 (95\% confidence interval 1.04 to 6.51$)$ ) but not in the carers for people with learning disabilities (odds ratio $1.07(0.45$ to $2 \cdot 58)$ ). The ratio of seropositive to seronegative subjects was the same in both control groups. No subject had been immunised against hepatitis $A$ in the previous six months.

\section{Comment}

Although the number of subjects was small, the results indicate a significantly increased risk of infection with hepatitis A virus for sewage workers. Operators of high pressure water hoses used to unblock drains (jetting) may be infected from the aerosols generated since they frequently do not wear the respiratory protection provided. Sewage workers may also be infected from their equipment and protective clothing, which are often contaminated with faeces. Furthermore, they eat food in the sewage wagons and may not remove protective clothing before eating in the canteen. Smoking is also permitted at work. As a result of this study our department is undertaking the health education of sewage workers and the immunisation of those who are seronegative.

Selection bias among the sewage workers was eliminated by including all those employed by the two local authorities. Although most of the carers for people with learning disabilities from one of the authorities took part in the study, a selection bias here cannot be excluded. It would be interesting to test a larger sample of sewage workers for an association between length of employment and infection with hepatitis A virus, but the type of work done may be more relevant to the risk of infection. Infection with hepatitis A virus can now be added to leptospirosis (Weil's disease), giardiasis, ${ }^{5}$ and industrial waste as occupational hazards for sewage workers in Britain. Carers for people with learning disabilities seem to be at no greater risk of infection with hepatitis A virus than the general population.

We thank Mr S Farley and Mr P Stewart for performing the ELISA tests and Mr I Calvert for statistical advice.

1 Tilzey AJ, Palmer SJ, Barrow S, Perry KR, Tyrell H, Safary A, et al. Clinical trial with inactivated hepatitis $A$ vaccine and recommendations for its use. BMF 1992;304:1272-6.

2 Hepatitis A; a vaccine at last [editorial]. Lancet 1992;339:1198-9.

3 Timothy EM, Mephan P. Outbreak of infective hepatitis amongst sewage sludge spreaders. Communicable Disease Repon 1984;3:3.

4 Skinhoj P, Hollinger FB, Hovind-Hougen K, Lous P. Infectious liver disease in three groups of Copenhagen workers: correlation of hepatitis $\mathrm{A}$ infection to sewage exposure. Arch Environ Health 1981;36:139-43.

5 Heap BJ, McCulloch MLB. Giardiasis and occupational risk in sewage workers. Lancet 1991;338:1152.

(Accepted 4 March 1993) 